\title{
The cultural landscape of megalithic tombs in Denmark, reconstructed by soil pollen analysis
}

\author{
${ }^{\dagger}$ Svend Th. Andersen \\ The Geological Survey of Denmark and Greenland (GEUS), Copenhagen, Denmark
}

(Received 9 December 2008; final version received 7 January 2013)

\begin{abstract}
Forty-four pollen spectra from 25 megalithic tombs (5 dolmens and 20 passage graves) in eastern and northern Denmark reveal a highly varied landscape with remains of woodland, coppice woods or secondary woodland and open areas of grass and herb vegetation. Very often there are traces of tree burning. The dominant land-use was cereal growing on burnt sites and pasture. A long-fallow swidden rotation based on the burning of coppice, cereal growing, pasture and coppice regeneration is indicated.
\end{abstract}

Keywords: soil pollen spectra; megaliths; swidden rotation; land-use; agriculture; Neolithic

\section{Introduction}

Excavations and restorations of megalithic tombs in Denmark have revealed a wealth of information about the high cultural and technological level of the mound builders (e.g. Hansen 1993, Dehn et al. 1995, Dehn et al. 2000). The tombs thus bear evidence of a highly developed society, whose wealth permitted the building of magnificent monuments and the production and sacrifice of highly refined inventory. The tombs, however, give no visible evidence about the setting of the landscape in which they are built and the economic background for these extravagances. Nevertheless, the mounds themselves offer possibilities for revealing such information, if appropriate methods are employed.

\section{Pollen grains in soils buried in megalithic graves}

Underneath the mounds, traces of the land original surface often occur. In these soil horizons we can find pollen grains, which were deposited on the land surface and then buried in the soil by the soil fauna. Pollen grains buried in soils are destroyed by microorganisms within a few years in calcareous and aerobic soils but may be preserved for a very long span of years in more acid soils (Andersen 1979, Dimbleby 1985). The erection of a mound around a megalithic grave sealed off the original soil and hindered further breakdown of the pollen grains buried there. The pollen present in these soils is strictly of local origin (Andersen 1992). These pollen spectra are, therefore, narrowly focused in space and time and thus may reveal vegetational composition and possible management methods used by the mound builders at the mound site.

Sections through megalithic burial mounds have revealed that the earth used for building the mounds very often was taken from the land surface around the mounds. Pollen spectra from these layers may differ from the soil under the mound itself and, therefore, indicate variations of the vegetation around the graves (Dimbleby 1962, 1985, Andersen 1992).

The soils buried in megalithic mounds in Denmark are usually of the brown earth type, in which the pollen spectra reflect the most recent vegetation at the site. However, in cases of rapidly changing vegetation stages, differing pollen assemblages may have become mixed during the burial in the soil (Andersen 1992).

The practice of burning felled trees on the ground can be recognized because the pollen grains buried in the topmost soil have been deformed by the heat in a characteristic manner (Andersen 1990, 1992). Tree pollen affected in this way frequently occurs in the soil samples, an indication that tree vegetation has been felled and burned on the site. If a burnt area is invaded by herb vegetation, one may find pollen from the burnt trees mixed with pollen from the herb vegetation in the same soil sample (Andersen 1990).

This manuscript was finished in 1996 for a planned conference proceedings that unfortunately never was published. Before the death of the author in 2009 he gave his consent to the publication of the manuscript in DJA. The manuscript is published here in its original form with minor adjustments to comply with the reviewers' suggestions and journal requirements (Peter Rasmussen, GEUS).

${ }^{\dagger}$ Deceased. 


\section{The landscape of megalithic tombs in Denmark}

Soil samples were collected during a megalith restoration campaign and other archaeological investigations in Denmark. Samples from a few of the tombs were devoid of pollen, presumably because of very intensive biological breakdown. Forty-four pollen spectra were obtained from 25 tombs (5 dolmens and 20 passage graves), from the Middle Neolithic Period I A in eastern and northern Denmark (Figures 1 and 2). The tombs were situated on a more or less sandy till substrate, and the pollen spectra did not reflect geographical differences.

Landscape variation, as reflected by the 44 pollen spectra, is shown in Figure 3. This triangular diagram illustrates the representation of original woodland, secondary woodland or coppices and open land within the individual pollen spectra. Common English names for plant species follow Clapham et al. (1952), and Latin names follow Tutin et al. (1964-1980). Lime (Tilia cordata) was common before the introduction of agriculture, whereas early-successional trees such as hazel (Corylus avellana), birch (Betula sp.) and alder (Alnus glutinosa) were common in secondary woodlands created after disturbance of the original lime woodlands. Open areas are characterized by non-tree vegetation, mainly grasses and herbaceous plants. The triangular diagram in Figure 3, therefore,

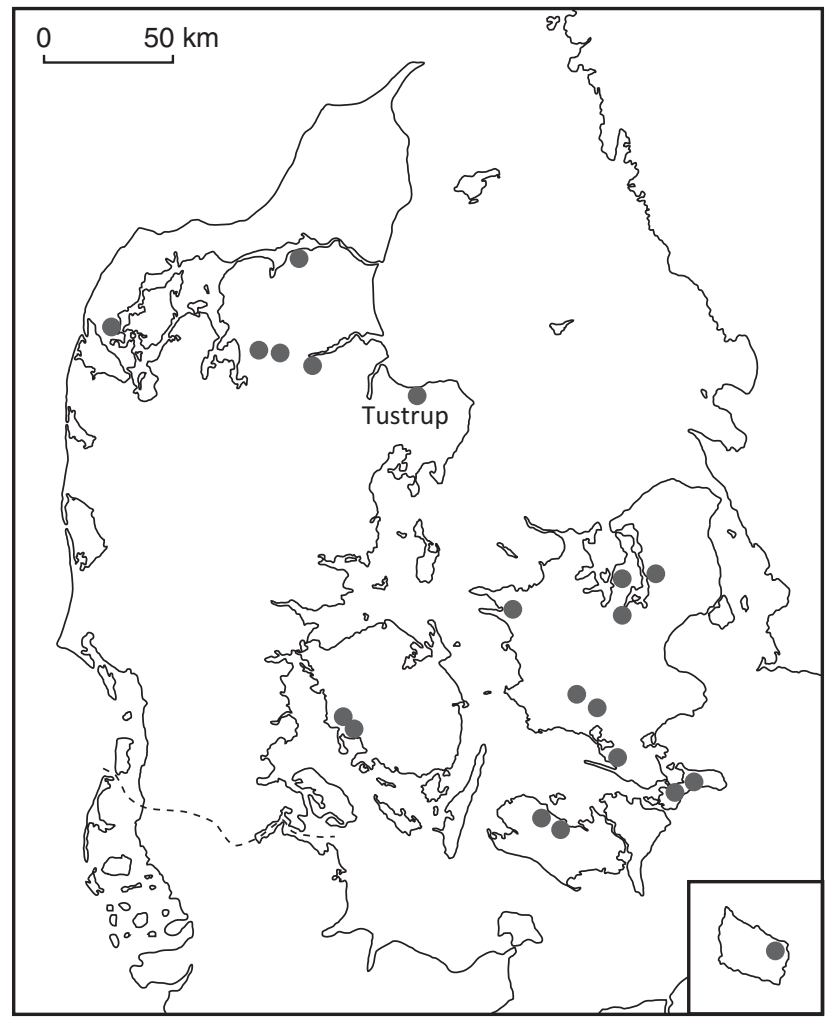

Figure 1. Map of Denmark showing the location of megaliths with pollen spectra from soil samples included in this study.

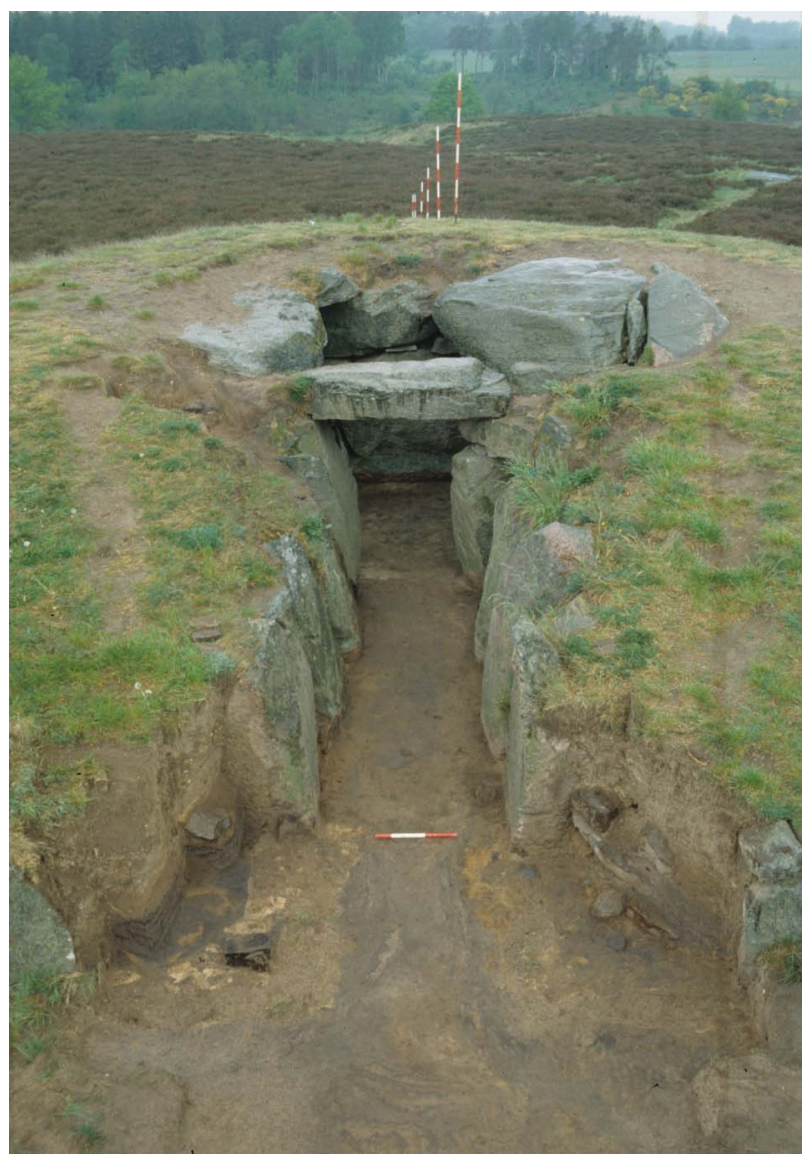

Figure 2. Previous to the restoration of the Tustrup passage grave, eastern Jutland, an excavation revealing the buried topsoil was carried out. During this excavation pollen samples of the different soil horizons under the mound were collected (photo: Torben Dehn).

reflects the occurrence of lime-woodland (dots in the lower left-hand corner), secondary woodland or coppice (dots in the lower right-hand corner) and sites invaded by herbaceous vegetation (uppermost corner). The circles around the dots in Figure 3 indicate sites where felled tree vegetation had been burned on the ground.

The wide distribution of dots within the triangle reflects the presence of a very diverse landscape at the time of megalithic tomb construction. A cluster of dots towards the lower left corner is dominated by lime and indicates relic lime woodland. These dots are somewhat separated from the baseline due to the presence of $20-30 \%$ herbaceous pollen. These relic lime woodlands from Middle Neolithic time were less dense than the undisturbed lime woodlands from earlier times (Andersen 1984). The lime woodland on three sites had been felled and burned just before the mounds were built. Another cluster of dots occurs in the lower right-hand corner. These dots indicate secondary woodland, which, in nearly all cases, had been burned just before the mound building. 


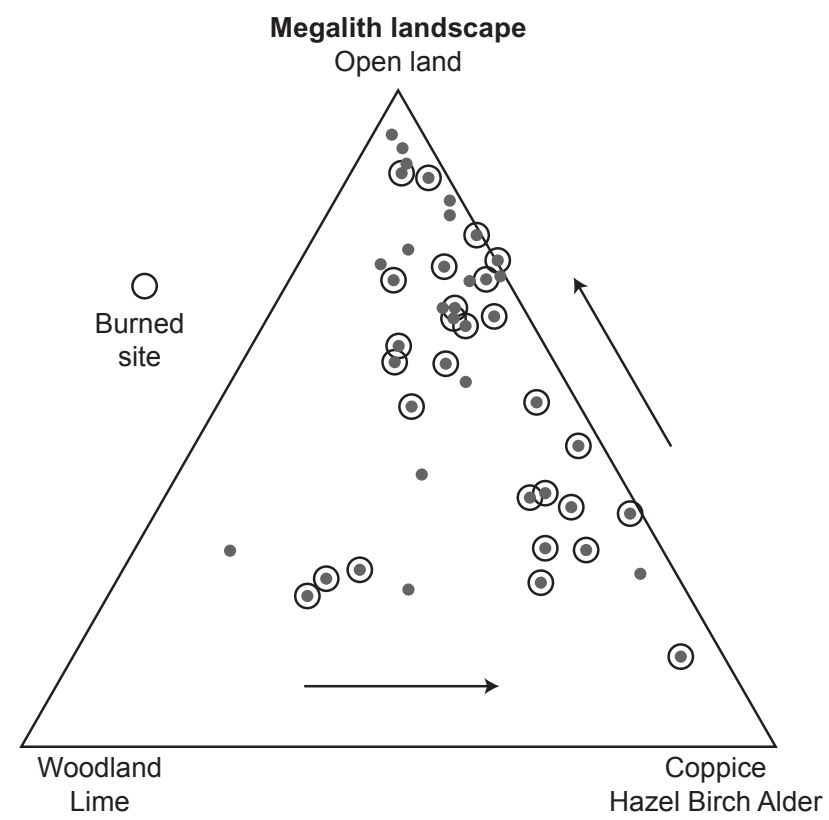

Figure 3. Triangular diagram, indicating landscape variation of the megalithic tombs according to pollen spectra from soil samples. Each dot represents a pollen spectrum from one soil sample. Lower left-hand corner, woodland $100 \%$. Lower right-hand corner, coppices $100 \%$. Uppermost corner, open land (herbs) $100 \%$. Open circles indicate pollen spectra where more than $20 \%$ of the tree pollen was deformed due to heating from ground fires.

Twenty-eight pollen spectra (64\%) are concentrated to the upper half of the triangle in Figure 3. These dots indicate sites where trees had been replaced by herbaceous vegetation. At the majority of these sites, trees had been burned prior to the invasion by herbs.

The pollen spectra from the megalithic tombs in Denmark indicate a highly diverse vegetation that was strongly influenced by human activity. Most of the former lime woodlands had been transformed into coppices, and the coppices, in many cases, had been invaded by herbaceous vegetation. Hazel, alder and birch were common in the secondary woodlands due to human interference. The woodlands had been felled and burned at 29 sites (66\%) either at the time when the mounds were built or prior to invasion by herbaceous vegetation. The wide use of fire indicates a swidden agriculture system (also known as slash-and-burn or shifting agriculture), where coppices were produced and then burned and used for agricultural purposes.

\section{Land-use in the megalith landscape}

The composition of the non-tree pollen reflects agricultural practice. There were three main components present, woodland herbs, grasses (and other herbs) and ribwort plantain (Plantago lanceolata, Andersen 1992). Figure 4 shows the occurrence of these plants in the individual pollen spectra.

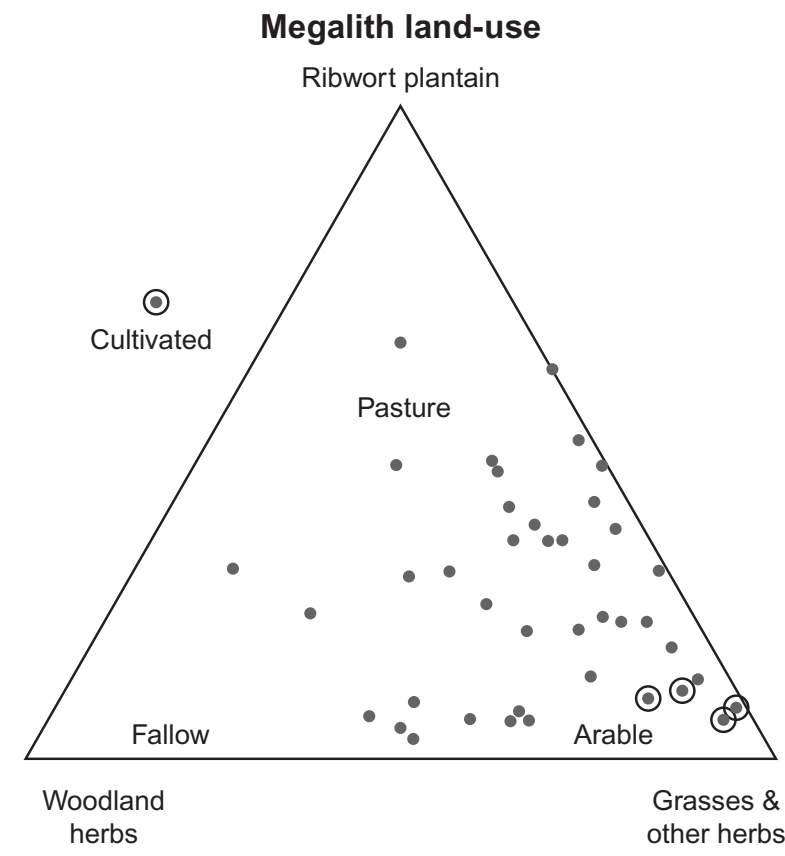

Figure 4. Land-use in megalith time according to the composition of the non-tree pollen in soil samples. Lower left-hand corner, woodland herbs $100 \%$. Lower right-hand corner, grasses and other herbs $100 \%$. Uppermost corner, ribwort plantain $100 \%$. Open circles indicate pollen spectra with traces of cereal cultivation.

Woodland herbs, including bracken (Pteridium aquilinum) and mugwort (Artemisia), were associated with the coppice vegetation. The dots in the lower left-hand part of the triangular diagram in Figure 4 represent this herbaceous vegetation at coppice sites.

The grasses and other herbs indicate herb vegetation, which had invaded the burnt coppice areas. Five of these sites show distinctive traces of cereal cultivation (enclosed by circles in Figure 4). Plants, which prefer bare soil and avoid dense herb vegetation, were particularly frequent at these sites (12-26\%) together with cereals (barley and wheat, Table 1). The pollen spectra in the lower right-hand corner, therefore, indicate burnt sites used for cereal cultivation.

Sites with frequent ribwort pollen (20-60\%) occupy a major part of the triangle in Figure 4 (26-50\%). Grazing by livestock prevents the flowering of grasses and most other herbs, whereas ribwort plantain continues to produce new flowering spikes from leaf rosettes. The enormous quantities of ribwort pollen at the megalithic sites, therefore, indicate widespread grazing of the herb vegetation, which had invaded the burnt coppice sites.

\section{Swidden rotation in megalithic time}

The pollen spectra from the Middle Neolithic megalith sites indicate that lime woodlands and secondary woodlands of lime, birch, hazel and alder had been felled and burned for 
Table 1. Bare soil plants, Crucifer family, Ribwort Plantain and grasses (in \% of non-tree pollen) and deformed tree pollen (in \% of tree-pollen).

\begin{tabular}{|c|c|c|c|c|c|}
\hline Bare soil plants & 25.9 & 26.3 & 11.8 & 12.7 & 13.0 \\
\hline Barley, Hordeum type & 7.0 & 4.4 & 3.9 & 6.3 & 3.9 \\
\hline Wheat, Triticum type & - & 0.6 & 0.8 & 0.2 & 1.3 \\
\hline Sheep's Sorrel, Rumex acetosella & 15.0 & 13.4 & 2.4 & 3.9 & 1.3 \\
\hline Cornflower, Centaurea cyanus & 0.7 & 1.3 & 0.8 & 0.5 & - \\
\hline Knotgrass, Polygonum aviculare & 1.2 & 4.4 & - & 0.5 & 6.4 \\
\hline Persicaria, Polygonum persicaria & - & - & - & 0.2 & - \\
\hline Tartarian Buckwheat, Fagopyrum tataricum & 0.5 & - & - & - & - \\
\hline Corn Spurrey, Spergula arvensis & - & - & - & 0.2 & - \\
\hline Field Madder, Sherardia arvensis & - & - & - & 0.2 & - \\
\hline Hemp-nettle, Galeopsis type & - & 0.6 & - & - & - \\
\hline Goosefoot family, Chenopodiaceae & 1.2 & - & 1.6 & - & - \\
\hline Great Plantain, Plantago major & - & - & 1.6 & - & - \\
\hline Annual Knawel, Scleranthus annuus & 0.2 & - & - & - & - \\
\hline Perennial Knawel, Scleranthus perennis & - & 1.3 & - & 0.7 & - \\
\hline Stonecrop, Sedum & - & - & 0.8 & - & - \\
\hline Sheep's-bit, Jasione montana & - & - & - & 0.2 & - \\
\hline Crucifer family, Brassicaceae & 6.5 & 18.6 & 3.4 & 0.7 & 6.4 \\
\hline Ribwort Plantain, Plantago lanceolata & 6.1 & 10.3 & 9.4 & 6.6 & 1.3 \\
\hline Grasses & 42.4 & 29.4 & 23.6 & 64.0 & 70.1 \\
\hline Deformed tree pollen & 21.2 & 48.7 & 54.8 & 15.2 & 30.2 \\
\hline
\end{tabular}

use in cereal cultivation and livestock grazing. Soils under burnt tree vegetation are well suited for the cultivation of cereals for a short period (Steensberg 1955, 1979, Reynolds 1977, Ehrmann et al. 2009). Due to mixing of the pollen, an arable stage is difficult to trace at sites where extended periods of livestock grazing followed. Cereal cultivation can, therefore, only be traced in those cases where the mounds were built in arable fields. However, the presence of ard marks under many megalithic mounds (Kristiansen 1990, Thrane 1991) indicates that cereal cultivation was more common than suggested by the pollen spectra.

Widespread use of a swidden rotation system in megalithic time can, therefore, be suggested (Figure 5). This changed lime woodlands to secondary woodlands which served as fallow land. These were then felled and burned, to be used for cereal cultivation and prolonged livestock grazing. These phases occurred simultaneously in the megalith landscape, and mound building took place during various stages (indicated by broken lines in Figure 5). It can also be surmised that secondary woodlands were reestablished by invasion of trees on abandoned pastures.

\section{Swidden rotation at the Tustrup megaliths}

The pollen buried in the brown-earth soils reflect vegetation at the sites shortly before and at the time of mound construction. A longer sequence of vegetation phases may be preserved in soils with a low biological activity. The pollen grains are transported downwards from the surface, but mixing of the pollen assemblages is less pronounced than in fertile soils. A vegetational sequence can, therefore, be recognized in soils of this type (Andersen 1979).
At Tustrup on Djursland, East Jutland (Figures 1 and 2), samples were collected beneath a passage grave and a dolmen originally excavated by P. Kjærum (Kjærum 1958). A sequence of vegetation phases could be recognized in a sandy soil beneath the passage grave (Figure 6). In the oldest phase 1, tree vegetation (birch dominant) was replaced by herb vegetation with dominant ribwort plantain. High frequencies of birch pollen deformed by heating indicate that the coppice had been burned before it was replaced by grazed herb vegetation. In phase 2, the grazing was abandoned and the area was invaded by birch trees. The birch coppice was burned again, and there are traces of renewed grazing (plantain). A birch coppice was re-established in phase 3 and was felled at the time when the grave mound was built.

The vegetation sequence at the passage grave at Tustrup shows that birch coppices were burned and used for pasture and then re-established in a swidden rotation system. Ard marks indicate cultivation at the site, but a horizon with cereal pollen could not be identified. It can be suggested that cereals were cultivated at the beginning of the first grazing phase.

A shorter sequence was preserved in a soil found beneath the dolmen at Tustrup (Figure 6). Here, a birch coppice was burned and then replaced by pasture vegetation.

\section{Swidden rotation as a basis for the economy of the megalith people}

The pollen analyses from soils in the megalithic graves indicate that the landscape around the mounds was used 


\section{Megalith swidden rotation}

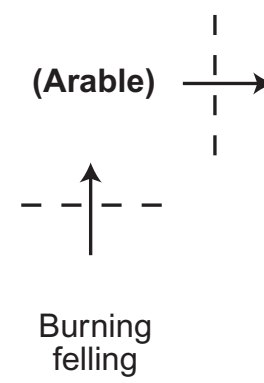

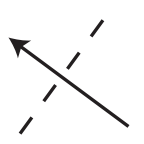

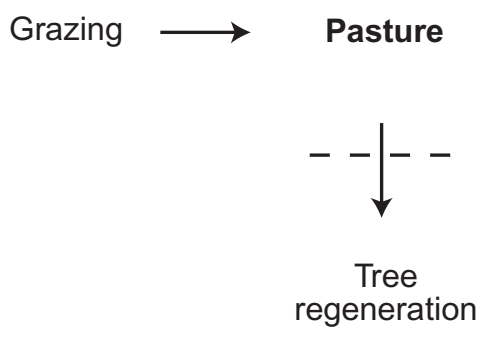

Secondary woodland Lime Birch Hazel Alder

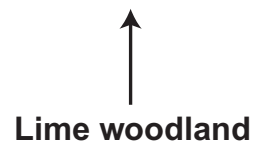

Figure 5. Model for swidden rotation in megalith time based on pollen analyses of soil samples. The broken lines indicate levels represented by pollen spectra.

intensively for swidden rotation, where coppice woods were burned and re-established after cereal cultivation and grazing. Birch coppices are easily developed by self- sowing (Linkola 1916, Grönlund 1995) and trees such as lime, hazel and alder can be rejuvenated by sprouting from the stumps of felled trees (Worsøe 1979).

In historic time in Finland, barley was grown for up to eight seasons on swidden sites after a fallow period of 15-40 years (Voionmaa 1987, Grönlund 1995). Swidden rotation also improves pasture for cattle (pasture burn-clearing, Massa 1987). Similarly, the use of long-fallow coppice rotation in megalith time provided a basis for cultivation of crops and production of cattle fodder without necessity for manuring. The purpose of the swidden rotation thus appears to be twofold: cultivation of cereal crops and production of livestock, the latter of which was probably the more important (compare Madsen 1982, Jensen 1994). Both products were essential for the economy of the megalith people.

Swidden rotation requires extensive areas and is profitable only as long as the rotation cycles remain long enough, however, increased population growth may necessitate a shortening of the rotation cycles, thereby diminishing crops (Grönlund 1995). In eastern Finland, overexploitation led to development of arable cultivation on permanent fields (Grönlund 1995). Scarcity of trees and very high percentages of plantain at many megalith sites in Denmark (Figures 3 and 4) might be an indication of overexploitation. Such overexploitation might have contributed to a greater emphasis on intensive cereal growing on permanent fields in the Middle Neolithic stages A II-V, which followed the period of megalith construction (MNA I, Jensen 1994).

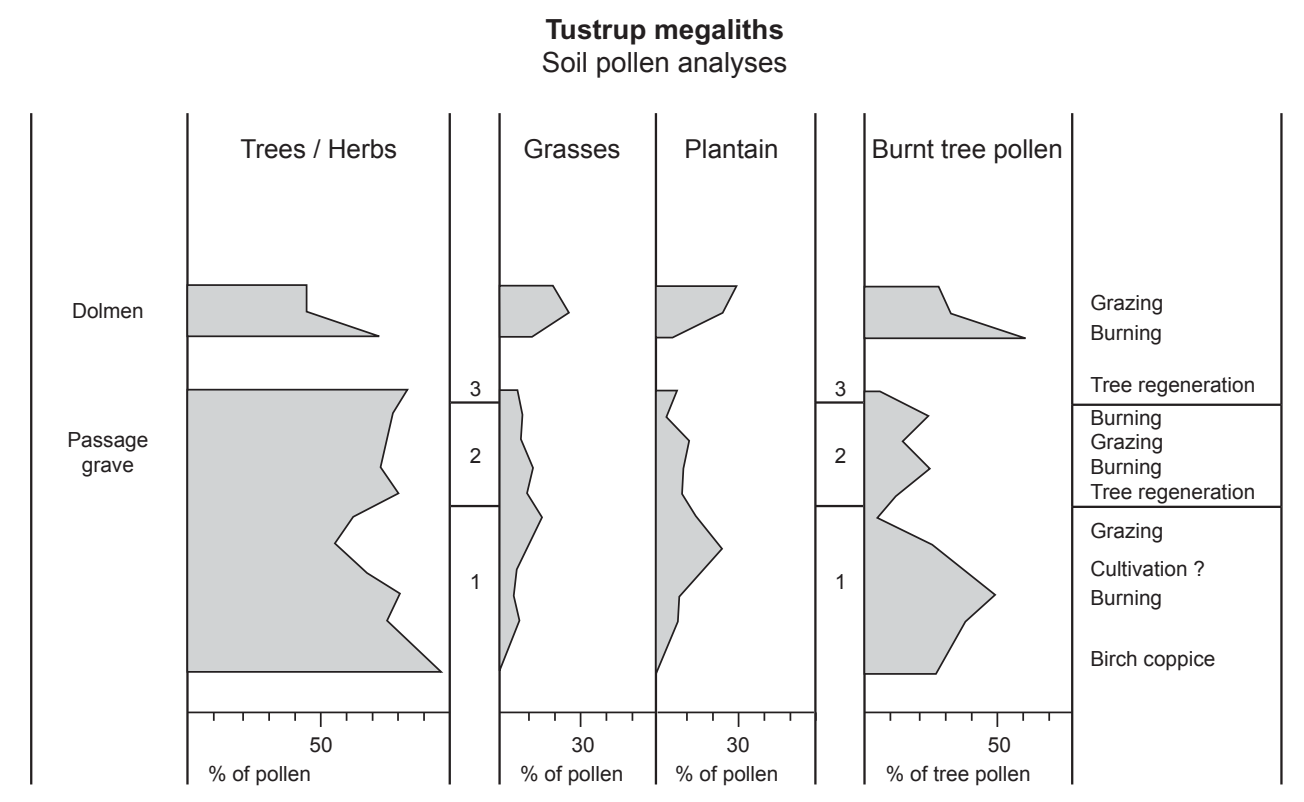

Figure 6. Pollen diagrams from soils under megalithic graves at Tustrup, eastern Jutland. The soils were $3 \mathrm{~cm}$ deep (dolmen) and $15 \mathrm{~cm}$ deep (passage grave), respectively. 


\section{Acknowledgements}

The examination of soil samples from burial mounds was part of a joint research project between the National Forest and Nature Agency (now: Danish Nature Agency) and The Geological Survey of Denmark and Greenland. The author wishes to thank the excavators, S. Hansen and T. Dehn in particular, for help and information given to him. B. Stavngaard prepared the samples, S. Veng Christensen typed and J.A. Wolin revised the manuscript.

\section{References}

Andersen, S.T., 1979. Brown earth and podzol: soil genesis illuminated by microfossil analysis. Boreas, 8, 59-73.

Andersen, S.T., 1984. Forests at Løvenholm, Djursland, Denmark, at present and in the past. Det Kongelige Danske Videnskabernes Selskab. Biologiske Skrifter, 24, 1.

Andersen, S.T., 1990. Pollen spectra from the double passagegrave, Klekkendehøj, on Møn. Evidence of swidden cultivation in the Neolithic of Denmark. Journal of Danish Archaeology, 7 (1988), 77-92.

Andersen, S.T., 1992. Early and Middle-Neolithic agriculture in Denmark: pollen spectra from soils in burial mounds of the Funnel Beaker Culture. Journal of European Archaeology, 1, 153-180.

Clapham, A.R., Tutin, T.G. and Warburg, E.F., 1952. Flora of the British Isles. Cambridge: Cambridge University Press.

Dehn, T., Hansen, S.I. and Kaul, F., 1995. Kong Svends Høj. Restaureringer og undersøgelser på Lolland 1991. Stenaldergrave i Danmark, bind 1.

Dehn, T., Hansen, S.I. and Kaul, F., 2000. Klekkendehøj og Jordehøj. Restaureringer og undersøgelser 1985-90. Stenaldergrave i Danmark, bind 2.

Dimbleby, G.W., 1962. The development of British heathlands and their soils. Oxford Forestry Memoirs 3. Oxford: Clarendon Press.

Dimbleby, G.W., 1985. The palynology of archaeological sites. London: Academic Press.

Ehrmann, O., von, Rösch, M. and Schier, W., 2009. Experimentelle Rekonstruktion eines jungneolithischen Wald-Feldbaus mit Feuereinsatz - ein multidisziplinäres
Forschungsprojekt zur Wirtschaftsarchäologie und Landschaftsökologie. Prähistorische Zeitschrift, 84, 44-72.

Grönlund, E., 1995. A palaeoecological study of land-use history in East Finland. University of Joensuu, Publications in Sciences, no. 31, 1-44.

Hansen, S., 1993. Joettestuer i Danmark. Konstruktion og restaurering. Skov- og Naturstyrelsen.

Jensen, H.J., 1994. Flint tools and plant working. Hidden traces of stone age technology. A use wear study of some Danish Mesolithic and TRB implements. Aarhus: Aarhus University Press.

Kjærum, P., 1958. Storstensgrave ved Tustrup. Kuml, 1957, 9-23.

Kristiansen, K., 1990. Ard marks under barrows: a response to Peter Rowley-Conwy. Antiquity, 64, 322-327.

Linkola, K., 1916. Studien über den Einfluss der Kultur auf die Flora in den Gegenden nördlich vom Ladogasee. I. Allgemeiner Teil. Acta Societatis pro Fauna et Flora Fennica, 45 , no. 1 .

Madsen, T., 1982. Settlement systems of early agricultural societies in East Jutland, Denmark: A regional study of change. Journal of Anthropological Archaeology, 1, 197-236.

Massa, I., 1987. Pasture burn-clearing as a method of colonization in northern Fennoscandia. Suomen Antropologi, 2, 235-240.

Reynolds, P.J., 1977. Slash and burn experiment. Archaeological Journal, 134, 307-318.

Steensberg, A., 1955. Med Bragende Flammer. Kuml, 1955, 65-130.

Steensberg, A., 1979. Draved. An experiment in stone age culture. Burning, sowing and harvesting. Copenhagen: The National Museum of Denmark.

Thrane, H., 1991. Danish plough-marks from the Neolithic and Bronze Age. Journal of Danish Archaeology, 8 (1989), 111-125.

Tutin, T.G., et al., eds., 1964-1980. Flora Europaea. Cambridge: Cambridge University Press.

Voionmaa, V., 1987. History of the Karelian tribe in Finland. Suomen Antropologi, 12, 207-212.

Worsøe, E., 1979. Stcevningsskovene. Copenhagen: Danmarks Naturfrednings forenings Forlag. 